\title{
The Tufas of Pyramid Lake, Nevada
}

\section{BACKGROUND}

Pyramid Lake is the site of some of the Earth's most spectacular tufa deposits. Tufa is a rock composed of calcium carbonate $\left(\mathrm{CaCO}_{3}\right)$ that forms at the mouth of a spring, from lake water, or from a mixture of spring and lake water. The explorer John C. Fremont (1845) wrote about the tufas during his 184344 expedition and named the lake after the pyramidal-shaped island that lies along the east shore of the lake (fig. 1). The Paiute name for the island is Wono, meaning cone-shaped basket. The Paiute name for the lake is Cui-Ui Panunadu, meaning fish in standing water.

The U.S. Geological Survey, in cooperation with the Pyramid Lake Paiute Tribe, has obtained radiocarbon ages of many of the tufa deposits that border Pyramid Lake in order to obtain a record

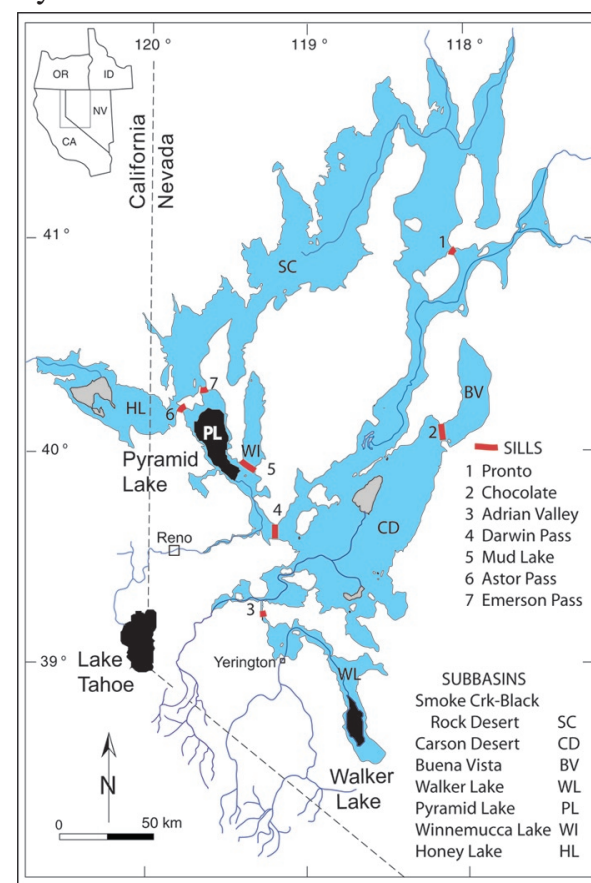

Figure 2. Pluvial Lake Lahontan at its highstand about 15,000 years ago. The black areas indicate perennial lakes that exist today. The gray areas indicate ephemeral lakes and sinks. The blue area indicates the surface area of Lake Lahontan at its highstand. The red lines indicate overflow points (sills) between subbasins. Sill elevations: Darwin Pass (1,265 m), Mud Lake (1,177 m), Astor Pass

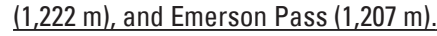

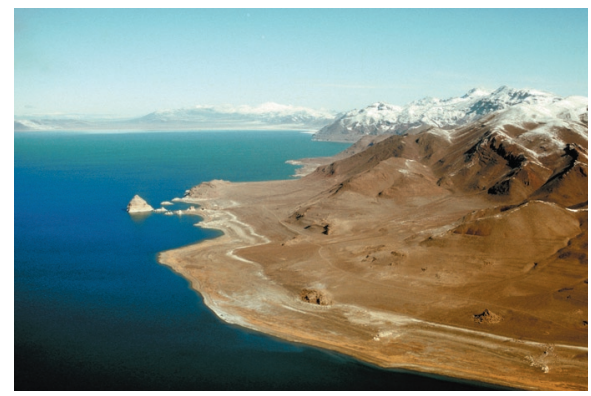

Figure 1. Pyramid Island along the east shore of Pyramid Lake.

of lake level change for the past 35,000 years (Benson, 1994).

\section{THE FORMATION OF TUFAS}

Most of the tufas formed between 26,000 and 13,000 years ago when the climate was much wetter, and Pyramid Lake was joined to lakes in nearby subbasins. Pluvial lakes, such as Lake Lahontan, formed during this wetter climate. These lakes are transitional in nature, and today, many are gone or exist only as remnants. Pyramid Lake is one of seven water bodies that coalesced to form pluvial Lake Lahon$\tan$ (fig. 2). At its highstand, Lake Lahontan was $281 \mathrm{~m}$ deep (compared to

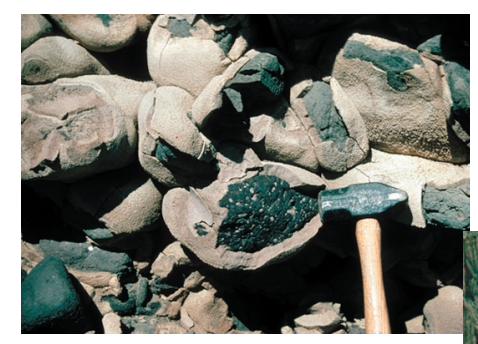

Figure 3. Dense tufa coating volcanic cobbles in the Terraced Hills area at the north end of Pyramid Lake. $106 \mathrm{~m}$ in 2004) and covered $22,800 \mathrm{~km}^{2}$, a surface area slightly larger than presentday Lake Ontario.

Tufas in the Pyramid Lake subbasin were first mentioned in scientific literature by Fremont (1845), who erroneously believed they had formed above water. Tufa mounds formed when springs discharged from the bottom of Pyramid Lake, supplying calcium that combined with carbonate dissolved in lake water to form the mounds. The thickest tufa deposits formed near lake-bottom sites of

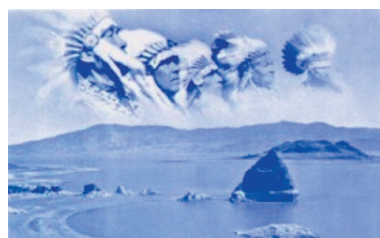

ground-water discharge, and at overflow elevations where the lake was held at near-constant levels for long periods of time.

\section{TUFA VARIETIES AND FORMS}

Russell (1885) was the first to suggest that there were three tufa varieties, including lithoid (dense), thinolitic (crystalline) and dendritic (branching) (figs. $3,4,5)$. Two other varieties have been noted in the Pyramid Lake area: a finegrained carbonate that cements sand and gravel forming beachrock (fig. 6), and a thin white porous carbonate that coats the outer surfaces of older tufas (fig. 7).

Tufa varieties combine to become tufa forms. Common forms include: (1) tufa pillows (fig. 8), composed of branching tufa and dense tufa nodules (fig. 5); (2) tufa tubes, composed of dense or branching varieties of tufa that sometime surround a thinolitic crystal mesh (fig. 4); (3) tufa sheets and drapes, which are primarily composed of branching tufa; and (4) tufa spheres or barrels, commonly composed of one

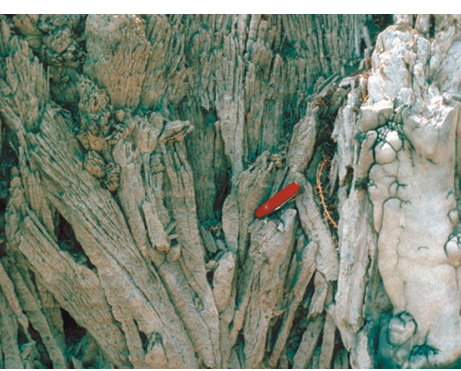

Figure 4. Thinolite crystals exposed at the base of the Blanc Tetons site.

or more layers of thinolitic crystals. In some situations, tufa forms combine to create tufa megaforms, such as tufa mounds (fig.7) and tufa reefs (figs. 8, 9). The largest collection of mounds occurs at the north end of Pyramid Lake at the Needles Rocks site. The locations of tufas depicted in this fact sheet are shown in Figure 10. 


\section{THE ELEVATION OF TUFA DEPOSITS AND THEIR RELATION TO OVERFLOW POINTS (SILLS)}

Because tufas form in lake water, it follows that their vertical growth is

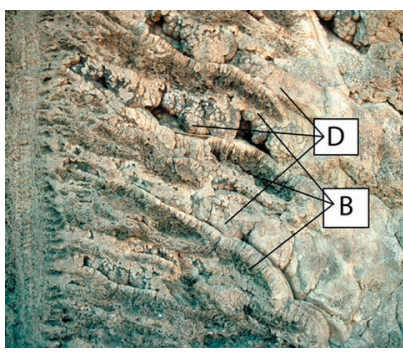

Figure 5. Tufa pillows at Doghead Rock composed of branching tufa (B) and dense (D) tufa pendants and nodules.

limited by lake level. In the Pyramid Lake subbasin, the elevations of the tops of many tufa mounds correspond to elevations of intersubbasin overflow points, or sills (fig. 2). When the level of Pyramid Lake was held constant by overflow to an adjacent subbasin, erosion of tufa and sediment occurred at and slightly above the overflow level, and deposition of tufa occurred below the overflow level. Terraces were created by both erosional and constructional processes. In addition, many other reef-like tufa deposits formed on rocky headland areas when the level of Pyramid Lake was kept relatively constant by overflow to adjacent lake subbasins.

Many of the tufas illustrated in this and other reports (Benson, 1994; Benson, 2004) have been dated using the radiocar-

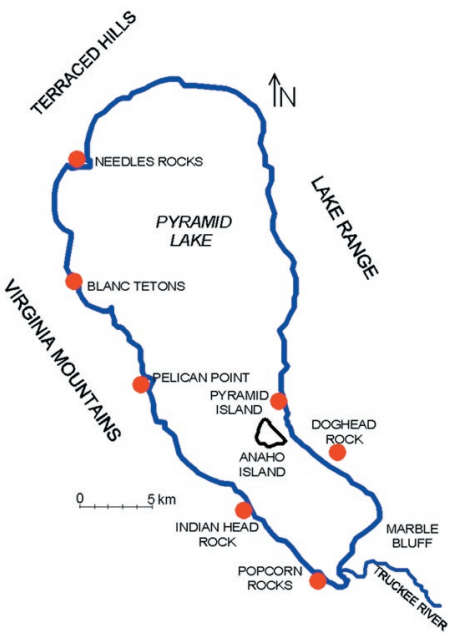

Figure 10. Locations of tufa sites discussed in this fact sheet. bon method (Benson and others, 1995). The elevations and ages of the tufa allow us to construct a lake-level history for the last 35,000 years. The data indicate that Lake Lahontan rose sharply about 26,000 years ago and was maintained at about $1,265 \mathrm{~m}$ for the next 7,000 years by overflow to the Carson Desert. After a brief fall to less than 1,250 m, Lake Lahontan rose rapidly to its highstand $(1,335 \mathrm{~m})$ about 15,000 years ago and then fell rapidly between 14,000 and 13,000 years ago. by removal of the lake sediment that surrounds them, may acquire additional calcium carbonate. The Needles Rocks area has experienced continued discharge of calcium-bearing waters into the bases of the tufa mounds. This younger calcium carbonate fills preexisting pore spaces in the tufa or adds calcium carbonate to the outside of a tufa. Many of the bases of tufa mounds that surround Pyramid Lake have been cemented with younger tufa, as indicated by the presence of "girdles" of calcium carbonate. Existing data indicate that the level of Pyramid Lake did not exceed the elevation of Mud Lake Sill which ranged from 1,177 to $1,183 \mathrm{~m}$ during the past 8,000 years (Benson and others, 2002), suggesting that cementation of the old tufa mounds occurred during that time interval.

\section{—Larry Benson}

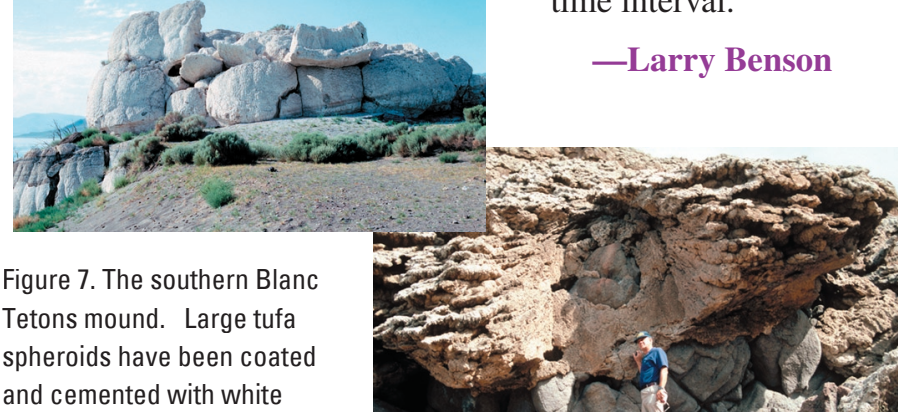

Figure 8. Tufa pillows making up a reef-like tufa on Anaho Island.

porous tufa.

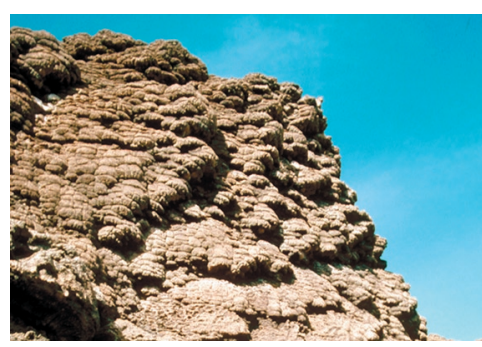

Figure 9. Tufa reefs coating Marble Bluff.

\section{RECENT TUFA FORMATION}

Deposition of tufa megaforms appears to have ended with the fall of Lake Lahontan between 14,000 and 13,000 years ago. We do not know why tufa deposition essentially ceased; however, decreases in the discharge of lake-bottom springs may have sharply lessened the amount of calcium available for tufa precipitation. Accurate dates for recent encrusting varieties of tufa are not available, in part because it is not known how much "old" carbon was introduced into the tufas by ground-water sources during their precipitation (Benson and others 1995). In addition, tufas re-exposed to lake water, either by a rise in lake level or

\section{REFERENCES}

Benson, L.V., 1994, Carbonate deposition, Pyramid Lake subbasin, Nevada: 1 . Sequence of formation and elevational distribution of carbonate deposits (tufas): Palaeogeography, Palaeoclimatology, Palaeoecology, v. 109, p. 55-87.

Benson, L.V., 2004, The tufas of Pyramid Lake, Nevada: U.S. Geological Survey Circular 1267, $14 \mathrm{pp}$.

Benson, L.V., Kashgarian M., and Rubin, M., 1995, Carbonate deposition, Pyramid Lake subbasin, Nevada: 2. Lake levels and polar jet stream positions reconstructed from radiocarbon ages and elevations of carbonate deposits (tufas): Palaeogeography, Palaeoclimatology, Palaeoecology, v. 117, p. 1-30.

Benson, L., Kashgarian, M., Rye, R., Lund, S., Paillet, F., Smoot, J., Kester, C., Mensing, S., Meko, D., and Lindstrom, S., 2002, Holocene multidecadal and multicentennial droughts affecting northern California and Nevada: Quaternary Science Reviews v. 21, p. 659-682.

Fremont, J. C., 1845, Report of the exploring expedition to the Rocky Mountains in the year 1843 and to Oregon and north California in the years 1843-44: Washington D.C.

Russell, I. C., 1885, Geological history of Lake Lahontan, a quaternary lake of northwestern Nevada: U. S. Geological Survey Monograph 11, 287 pp.

For more information, contact: Chief, Branch of Regional Research U.S. Geological Survey, MS 418 Denver Federal Center, Box 25046 Denver, CO 80225-0046 